\title{
NUANCED GENDER PERCEPTIONS: TOURISM BUSINESS CAPABILITIES IN KWAZULU-NATAL, SOUTH AFRICA
}

\author{
Nompumelelo NZAMA \\ University of Zululand, Department of Recreation and Tourism, KwaDlangezwa 3886, South Africa, e-mail: NzamaN@unizulu.ac.za \\ Ikechukwu O. EZEUDUJI* \\ University of Zululand, Department of Recreation and Tourism KwaDlangezwa 3886, South Africa, e-mail: ezeudujii@unizulu.ac.za
}

Citation: Nzama, N., \& Ezeuduji, I.O. (2021). NUANCED GENDER PERCEPTIONS: TOURISM BUSINESS CAPABILITIES IN
KWAZULU-NATAL, SOUTH AFRICA. GeoJournal of Tourism and Geosites, 35(2), 372-380. https://doi.org/10.30892/gtg.35215-661

\begin{abstract}
We explored nuanced gender perceptions regarding the influences that business capabilities may have on tourism-related business operations in Durban, KwaZulu-Natal. We used structured questionnaire to collect data from 150 tourism-related entrepreneurs and managers. This study made no conclusive finding that gender does play a role with regard to differentiating business success or performance, as reported in some literature. However, marketing capability is the main factor that influence business performance.
\end{abstract}

Key words: gender nuances, business performance, business operations, business capabilities, sub-Saharan Africa

\section{INTRODUCTION}

Durban is the commercial hub of the KwaZulu-Natal Province, which is one of the nine provinces of South Africa. Tourism has a significant contribution in the local economy of KwaZulu-Natal, this grew from a reported R9billion contribution to the Provincial Gross Domestic Product (GDP) in 2014 to above R10billion in 2018 (Tourism KwaZulu-Natal, 2019 https://www.zulu.org.za/). The study by Ezeuduji and Nkosi (2017) posits that the KwaZulu-Natal province is very popular for its unique heritage and diverse cultural experiences. Most tourists who visit this province are mostly attracted by the nature, culture, warm weather, and beach experience, which are offered in both its coastal and inland regions. KwaZulu-Natal Tourism competes on tourist volumes and the quality of visitor experience. Therefore, tourism-related entrepreneurship is vital in this province to service domestic and international tourists, and the local community. Developing countries are putting more emphasis on building stronger economies by promoting entrepreneurship. South Africa, like any other developing country developed policies that place high value on entrepreneurship (Business Environment Specialist, 2013 http://www.sbp.org.za/uploads/media/SBP_Alert). The Government of South Africa has identified tourism as a huge potential for economic growth (Tshabalala and Ezeuduji, 2016), hence entrepreneurship in the tourism industry is desirable. Nonetheless, a study by Iwu et al. (2016) reveals that entrepreneurial activity in South Africa is relatively low.

Gender mainstreaming has become part of the entrepreneurship studies. Mainstreaming is a concept that essentially paves way for a varied approach that acknowledges and values the variance that may exist among different genders. The ultimate goal of gender mainstreaming is to achieve gender equality (Shepard, 2015). According to Sarfaraz et al. (2014), economic development is difficult to achieve without the active participation of women. Unfortunately, South African tourism industry has inadequate women participation. Research shows that women in tourism and other sectors' businesses occupy low position (Tshabalala and Ezeuduji, 2016) and they have less opportunities for advanced career development (Ferguson, 2011). This predicts that South African women may remain in the periphery of economic development. Research also reports that the performance of female-owned businesses have been lower and very constrained compared to male-owned businesses (Marlow and McAdam, 2013), as they are likely to close down and less likely to make sustained profit (Fairlie and Robb, 2009). Literature on women entrepreneurship posits that there are many challenges (such as unfavourable societal perception, inadequate financial capital, lack of management capabilities, weak entrepreneurial networking) faced by South African women in business (Nxopo and Iwu, 2016; Nzama and Ezeuduji, 2020a; Nzama and Ezeuduji, 2020b; Tshabalala and Ezeuduji, 2016). Reports emanating from the entire Southern African Development Community (SADC) region show that men dominate management positions in the tourism industry (Nyaruwata and Nyaruwata, 2013; Global Entrepreneurship Monitor (GEM), 2012 https://www.gemconsortium.org/report/gem-2012-womens-report). There has been a call from the global community to empower women in all socio-economic activities, and promoting women entrepreneurship is a significant way to achieve that (Kimbu et al., 2019), specifically in the tourism industry with its high potential for economic growth (Mkhize and Cele, 2017).

Much gender-based entrepreneurship studies (such as Kimbu et al., 2019; Kokotović et al., 2016; Mkhize and Cele, 2017; Nxopo and Iwu, 2016; Sarfaraz et al., 2014; Todorović et al., 2016; Tshabalala and Ezeuduji, 2016; Vossenberg, 2013; Witbooi and Ukpere, 2011) focused on women entrepreneurship as a driver of gender equality, poverty reduction, and social

\footnotetext{
" Corresponding author
} 
development. They did not specifically explore gender-induced differences or perceptions, especially from the African perspective. This research therefore explored nuanced gender perceptions with regard to the influences that business capabilities may have on tourism business operations; and also sought if gender identity drives business performance, using the case of Durban Central Business District, situated in KwaZulu-Natal, South Africa.

\section{LITERATURE REVIEW}

\section{Gender discourse in entrepreneurship studies}

Across the world, entrepreneurship has been considered one of the viable development strategies resulting from its considerable socio-economic contributions (González-Sánchez, 2015; Hassan et al., 2014; Okeke-Uzodike et al., 2018; Todorović et al., 2016). Since the first publication of academic papers related to women entrepreneurship in the 1970s, the concept of women entrepreneurship has attracted many researchers owing to its significance contribution to social and economic development. Vossenberg (2013) and Sarfaraz et al. (2014), state that women entrepreneurship has an impact on achieving gender equality, social development and poverty reduction. Women entrepreneurship is recognised as a source of economic development (Ceptureanu and Ceptureanu, 2016), and the important role women entrepreneurs play has drawn attention of academics, governments, and non-governmental organisations (Moses et al., 2016; Tajeddini et al., 2017). Witbooi and Ukpere (2011) also indicate that many women entrepreneurs possess adequate level of expertise, skills, and creativity necessary to kick-start and manage entrepreneurial activities, however they often do not have equal access to resources such as information, education and finance, as male entrepreneurs (Kokotović et al., 2016; Todorović et al., 2016).

Research by Tajeddini et al. (2017) emphasises that men and women are equal, but cultural influence encourages women to adhere to duties such as managing households. Ceptureanu and Ceptureanu (2016) posit that generally, men and women possess very similar characteristics, but female-owned businesses tend to be smaller and yield lower incomes compared to male-owned businesses (Daniyan-Bagudu et al., 2016; Gidarakou, 2015; Ramadani, 2015; Tshabalala and Ezeuduji, 2016). Hence, the performance of female-owned businesses are lower and very constrained in comparison to male-owned businesses (Marlow and McAdam, 2013), and they are likely to close down and less likely to make profit (Fairlie and Robb, 2009).

\section{Gender discourse on managerial capabilities}

Managerial skills have been conceptualised as the main resource for managerial capabilities according to Wessels et al. (2017). It should be noted that Maurya and Sharma (2017) define managerial skills as the knowledge and the ability of business people in managerial positions to perform particular managerial tasks. According to Seyedinejat et al. (2014), managerial capability drives organisational success. The authors of this paper understand managerial capability to mean the ability to combine and coordinate resources (human, tangible and intangible) to add business value. In comparison to male entrepreneurs, female entrepreneurs tend to be more of transformational leaders. Guillet et al. (2019a) posit that women have great value of their teams and tend to invest in them by training and empowering its members; whereas, male managers appear to be very assertive and arrogant as opposed to showing respect and willingness to listen. Researchers (such as Schaap et al., 2008) also state that women entrepreneurs promote training for the subordinates in order to improve their understanding of how to implement and reach the performance targets as set by the organisation; whereas men are more likely to use position power and more dominance. Hence, women appear to lead by coaching, affiliation and allowing development of their subordinates. Regarding interpersonal skills, men and women entrepreneurs appear to practice different styles of management. Sudarmanti et al. (2013) show the communication differences found between male and female entrepreneurs; indicating that male entrepreneurs use power as a strategy to persuade the subordinates unlike female entrepreneurs.

Schaap et al. (2008) state that female managers perceive their power to be based on themselves and their positions, but they feel part of the team and identify with what the team is doing. Females tend towards approaches that are more transformational to leadership and interactive management. Schaap et al. (2008) indicate that women entrepreneurs emphasise task enjoyment, working with people, helping others, and making friends; whereas, men entrepreneurs use transactional leadership approach with emphasis on rewards, such as money. Vázquez-Carrasco et al. (2012) posit that women entrepreneurs have better capacity to organise and listen, and that women are more practical than men. Sudarmanti et al. (2013) mention that women entrepreneurs create a supportive, flexible and loyal environment within the business. Manzanera-Román and Brändle (2016) articulate that women specifically possess abilities such as perseverance and they have more social and human relations' abilities. Guillet et al.'s (2019a) study found that women entrepreneurs are perceived to be more sensitive and empathetic in their understanding of others (counterparts, subordinates, and customers). These abilities equip women entrepreneurs to be able to treat people with social sensitivity as they are dealing with people in and outside the organisation. In contrary, men tend to be detached and do not frequently engage with their staff as women leaders do. The authors (Manzanera-Román and Brändle, 2016) further state that these abilities or characteristics possessed by women give them advantage over their male counterparts as they are facilitators of entrepreneurship (Guillet et al., 2019b). Meanwhile, lacking technical skills has been identified as one of the reasons why women entrepreneurs usually operate in small and mostly informal enterprises. Sudarmanti et al. (2013) explicate that women entrepreneurs tend to have less experience, skills and managerial knowledge, compared with male entrepreneurs, hence, women entrepreneurs prefer (or are forced) to operate in micro enterprises.

\section{Gender discourse on marketing capabilities}

Previous literature (such as Kimosop et al., 2016; Welsh et al., 2017) maintain that there is a significant positive relationship between entrepreneurs' marketing capabilities and the business performance. Marketing capabilities equip entrepreneurs to grasp available opportunities to grow their enterprises and increase competitiveness (Welsh et al., 2017). 
Making a business known to potential consumers is one of the key aspects that affect business performance, as researchers (such as Yadav, 2018; Zeng and Gerritsen, 2014) alluded that the increase of tourists' flow at a destination relies more on proper marketing capabilities. Tshabalala and Ezeuduji (2016) identify a poor marketing strategy among women-owned businesses, pointing that the craft dealers are dispersed without any signage to show their presence. Furthermore, the study revealed that some women entrepreneurs do not have proper connection to the tourism industry to make their business known; hence, it is difficult to find customers. According to Jiyane (2014), women entrepreneurs prefer face-to-face communication to transfer, use and access information. In most cases, women entrepreneurs advertise their businesses by means of word-ofmouth (Biernacka et al., 2018; Tshabalala and Ezeuduji, 2016).

The emergence of information and communication technologies have changed the traditional frame for marketing, and brought smartness into the tourism industry. In the extant marketing landscape, having the presence of Internet, social media, blogs and Search Engine Optimisation (SEO), many platforms have been created for organisations to share information with potential customers. Chetty (2015) emphasises that a strong online presence of any organisation is considered a valuable asset for the business. Tourism organisations can use a variety of platforms of technology (such as TripAdvisor, Tripcast, social media, and HearPlanet) to share information about the organisation (Jovicic, 2019). By using such platforms, organisations also gain knowledge of what the tourists are expecting from the destination as they allow participant's review, which makes it easier for the marketing management to understand the target market and their needs and wants. Zeng and Gerritsen (2014), and Gidarakou (2015) advise tourism industry to take advantage of social media, as the industry relies on consumer opinion, word-of-mouth, destination reputation, and advertising. Though women are perceived as being particularly adept to social media, they have not been involved in technology as men (Orser and Riding, 2018). Meanwhile, women are less likely to apply their knowledge of social media to business development opportunities (Orser and Riding, 2018). The study also conclude that women lack confidence in their technology capabilities compared with men. This attitude towards technology generally affects access to certain markets that are technological intensive (Witbooi and Ukpere, 2011), such as the tourism market.

\section{RESEARCH DESIGN AND METHODS}

This research explored nuanced gender perceptions regarding the influences that business capabilities may have on tourism-related business operations in Durban Central Business District, in KwaZulu-Natal, South Africa. This requires a quantitative research approach using structured questionnaire survey to address research objectives (see Veal, 2011). We employed structured questionnaire survey using purposive sampling method, selecting those who have relevant knowledge (tourism business owners and managers) in tourism entrepreneurship, and who are willing to participate (Etikan et al., 2016; Nardi, 2018). The criteria of respondent inclusion in this study were that a tourism business is an enterprise that falls within the travel sector (transport and travel organisers), hospitality sector (accommodation and events), leisure and business sector, conservation sector, sports and recreation sector, gaming and lotteries sector, tourism support service sector and government tourism sector. The actual target population for this study is largely unknown because many of these businesses operating in this study area fall under the informal sector (not registered). This study therefore used non-probability (purposive) sampling to survey 150 respondents (75 males and 75 females) in their tourism businesses in Durban Central Business District under Ethekwini Metropolitan Municipality, KwaZulu-Natal, South Africa. We took special care in distributing questionnaires to create a fair comparison of the characteristics of male entrepreneurs against female entrepreneurs; and how they may respond to the business capabilities and operation factors. Because this study is non-probability in nature, we considered a sample size of 150 tourism entrepreneurs large enough to address the research objectives. Chawla and Sondh (2011) posit that a sample should not be too small to achieve data saturation or theoretical saturation.

We performed data analyses with the aid of IBM's Statistical Package for the Social Sciences (SPSS) software, version 25. We employed descriptive statistics (mostly frequencies), bivariate analyses (using Pearson's Chi-Square, Mann-Whitney U, and Spearman's Rank Correlation tests) and also performed multivariate analysis (conducting Reliability tests by the help of Cronbach's Alpha scores). Our initial data analysis proved that the ordinal variables used in measuring business operation statements (perceptions) have non-normal population distributions; hence we made use of Mann-Whitney U tests of comparing the means of responses by two independent groups to check if they significantly differ from one other. We hence compared responses to business operation statements with the respondents' demographic variables or characteristics (such as gender). We employed Mann-Whitney U tests based on the reported criteria that the dependent variables should have ordinal scale; whereas the independent variables should have only two groups; and the normality of distribution and homogeneity of variance do not prove true in a t-test (see George and Mallery, 2003; Veal, 2011). We employed Spearman's Correlation (two-tailed) test to check for relationships between the ordinal variables, enabling is to find out if there are positive or negative correlations between the variables that are being analysed (Veal, 2011); which for this particular study is between business operation statements and the perceived classification of business success. We also used Pearson's Chi-Square test to check for relationships between categorical / nominal data, where some variables that were previously measured in ordinal scale were recoded as categorical variable to support this analysis. Respondents' profiles were compared with business start-up motivation and perception of entrepreneurial success. We applied reliability test, a form of multivariate analysis, to calculate the level of internal consistencies of the variables that were used to describe factors that may influence business operations ('managerial and operational capabilities', 'marketing capability' and 'general entrepreneurial statements'). Finn et al. (2000) agree to the use of multivariate analysis in tourism research where a particular phenomenon may be influenced by a large number of variables (rather than a single one). Previous studies support that Cronbach's Alpha coefficient of between 0.5 and 0.7 should be acceptable in the social science studies, to show enough internal consistency of variables that are used to measure a factor or dimension (Chawla and Sondhi, 2011; George and Mallery, 2003). Nonetheless, Tavakol and Dennick (2011) state that low 
Cronbach's Alpha score may be achieved, if there exists a weak interrelationship among variables that are being used in the analysis, or if only few variables are used to explain or measure a particular dimension or construct. From the reliability tests conducted on the three business operation dimensions: 'managerial and operational capabilities', 'marketing capability' and 'general entrepreneurial statements'; dimensions achieved above 0.6 Cronbach Alpha coefficient, hence this study finds the variables contained in these dimension, internally consistent or related, to measure each of the dimensions.

\section{RESULTS AND DISCUSSION}

\section{Respondent's profile}

The results in Table 1 show that respondents in this study are mostly South Africans (about 89\%) and majority (about $61 \%$ ) of the respondents had business experience of not more than six years. Nsengimana et al. (2017) state that business experience influences the chances of entrepreneurial success. Results further show that entrepreneurs' motivation to start a tourism business to take an opportunity is somewhat higher (about 54\%) compared to the motivation of starting a business as means of survival (about 46\%). Mersha and Sriram (2019) posit that in most African countries, entrepreneurs are pushed into business by socio-economic factors (such as unemployment). This study however found that majority of respondents started businesses based on available opportunity. The level of education was also highlighted as an important factor in business operation (Fairlie and Robb, 2009; Ramadani, 2015). The results of this study show that 56\% of respondents have tertiary education. Majority of the respondents (57\%) perceived themselves as successful in their businesses, as about $44 \%$ perceived themselves as successful and about $13 \%$ as very successful.

Table 2. Business operation statements $(\%)$

\begin{tabular}{|c|c|c|c|c|c|}
\hline Statements & $\begin{array}{c}\text { Strongly } \\
\text { agree }\end{array}$ & Agree & Neutral & Disagree & $\begin{array}{l}\text { Strongly } \\
\text { disagree }\end{array}$ \\
\hline \multicolumn{6}{|c|}{ 2.1 Managerial and Operational Capabilities } \\
\hline $\begin{array}{l}\text { I have skills and experience in running a } \\
\text { tourism business }\end{array}$ & 35.3 & 56.7 & 4.7 & 3.3 & 0.0 \\
\hline $\begin{array}{l}\text { I give my employees the opportunity to come up } \\
\text { with ideas or decisions in running the } \\
\text { business }\end{array}$ & 23.3 & 51.3 & 18.7 & 6.7 & 0.0 \\
\hline $\begin{array}{l}\text { Male business managers are more capable } \\
\text { than female business managers }\end{array}$ & 8.7 & 8.7 & 13.3 & 54.0 & 15.3 \\
\hline $\begin{array}{l}\text { Male business managers are better managers } \\
\text { than female business managers }\end{array}$ & 7.3 & 11.3 & 12.0 & 52.0 & 17.3 \\
\hline $\begin{array}{l}\text { I send/arrange workshops for the staff } \\
\text { members to receive training. }\end{array}$ & 30.7 & 41.3 & 14.0 & 12.0 & 2.0 \\
\hline
\end{tabular}

Reliability statistics (Managerial and Operational Capabilities): Cronbach's Alpha = .664, N of items $=5$, Valid cases $=150(100 \%)$, Excluded cases $=0(0.0 \%)$, Total $=150$

\subsection{Marketing Capability}

I use Internet to market my business

I rely on different sources of media to get my business known.

I do research to find out the new market trends

I know very well how to offer my products and

deliver services to meet customer need (Product)

I use different promotion techniques to sell my products and services (Promotion)

\begin{tabular}{|l|l|l|l|l|}
\hline 42.0 & 32.7 & 8.0 & 14.0 & 3.3 \\
\hline 30.7 & 43.3 & 5.3 & 20.0 & 0.7 \\
\hline 36.7 & 41.3 & 6.0 & 16.0 & 0.0 \\
\hline 36.7 & 51.3 & 8.0 & 4.0 & 0.0 \\
\hline 41.3 & 38.7 & 2.7 & 17.3 & 0.0 \\
\hline
\end{tabular}

Reliability statistics (Marketing Capability): Cronbach's Alpha $=.875, \mathrm{~N}$ of items $=5$, Valid cases $=150(100 \%)$, Excluded cases $=0(0.0 \%)$, Total $=150$

\subsection{General Entrepreneurial Statements}

\begin{tabular}{|c|c|c|c|c|c|}
\hline I always bring new ideas in the business & 44.0 & 48.0 & 4.0 & 4.0 & 0.0 \\
\hline I am ambitious to bring change in my society & 33.3 & 51.3 & 11.3 & 3.3 & 0.7 \\
\hline I have been a powerful force for helpful change & 26.7 & 48.7 & 21.3 & 2.0 & 1.3 \\
\hline $\begin{array}{l}\text { I enjoy facing and overcoming obstacles to } \\
\text { my ideas }\end{array}$ & 40.3 & 46.3 & 8.7 & 3.4 & 1.3 \\
\hline I do not give up easily & 60.0 & 37.3 & 1.3 & 1.3 & 0.0 \\
\hline $\begin{array}{l}\text { I am great at turning problems into } \\
\text { opportunities }\end{array}$ & 36.7 & 53.3 & 8.0 & 2.0 & 0.0 \\
\hline I can spot a good opportunity easily & 41.3 & 50.0 & 4.7 & 2.7 & 1.3 \\
\hline \multicolumn{6}{|c|}{$\begin{array}{l}\text { Reliability statistics (General Entrepreneurial Statements): Cronbach's Alpha }=.774, \mathrm{~N} \\
\text { of items }=7, \text { Valid cases }=149(99.3 \%) \text {, Excluded cases }=1(0.7 \%) \text {, Total }=150\end{array}$} \\
\hline
\end{tabular}

Table 1. Respondents' profile $(\mathrm{N}=150)$

\begin{tabular}{|c|c|c|}
\hline Variable & Category & $\begin{array}{c}\text { Frequency } \\
(\%)\end{array}$ \\
\hline South & Yes & 88.7 \\
\hline African & No & 11.3 \\
\hline \multirow{2}{*}{ Gender } & Male & 50 \\
\hline & Female & 50 \\
\hline \multirow{4}{*}{ Ethnic group } & Black & 52.7 \\
\hline & White & 18.0 \\
\hline & Indian & 22.0 \\
\hline & Coloured & 7.3 \\
\hline \multirow[t]{2}{*}{ Age group } & Less than 40 years & 61.3 \\
\hline & 40 years and above & 38.7 \\
\hline \multirow{2}{*}{$\begin{array}{l}\text { Business } \\
\text { owner }\end{array}$} & Yes & 63.3 \\
\hline & No & 36.7 \\
\hline \multirow{2}{*}{$\begin{array}{l}\text { Business } \\
\text { manager }\end{array}$} & Yes & 58.7 \\
\hline & No & 41.3 \\
\hline \multirow{2}{*}{$\begin{array}{l}\text { Motivation to } \\
\text { start tourism } \\
\text { business }\end{array}$} & Took opportunity & 54.4 \\
\hline & Means of survival & $\begin{array}{l}54.4 \\
45.6\end{array}$ \\
\hline \multirow{2}{*}{$\begin{array}{l}\text { Level of } \\
\text { education }\end{array}$} & $\begin{array}{l}\text { Up to Secondary } \\
\text { School (Matric) }\end{array}$ & 44.0 \\
\hline & Tertiary Education & 56.0 \\
\hline \multirow{10}{*}{$\begin{array}{l}\text { Business } \\
\text { type }\end{array}$} & Accommodation & 16.0 \\
\hline & Food and Beverage & 26.7 \\
\hline & Events Management & 10.0 \\
\hline & Tour Operation & 3.3 \\
\hline & Travel Agency & 4.7 \\
\hline & Tour Guide & 2.7 \\
\hline & Car Rentals & 7.3 \\
\hline & Resorts & 2.0 \\
\hline & Consultancy & 2.7 \\
\hline & Souvenir Shop & 24.7 \\
\hline \multirow{2}{*}{$\begin{array}{l}\text { Number of } \\
\text { years in } \\
\text { business }\end{array}$} & Up to 6 years & 60.7 \\
\hline & 7 years and above & 39.3 \\
\hline \multirow{5}{*}{$\begin{array}{l}\text { Self- } \\
\text { classification } \\
\text { as an } \\
\text { entrepreneur }\end{array}$} & Very successful & 13.4 \\
\hline & Successful & 43.6 \\
\hline & Surviving & 32.2 \\
\hline & Struggling & 9.4 \\
\hline & Unsuccessful & 1.4 \\
\hline
\end{tabular}

\section{Business operation statements}

Respondents were asked to show their level of agreement or disagreement with the statements used to measure 'managerial and operational capabilities', 'marketing capability' and 'general entrepreneurial statements'. Previous study (Mersha and Sriram, 2019) posits that entrepreneurs in Africa lack business management skills as they are likely to be pushed into business by socio-economic challenges. Results in Table 2 contradict this statement and show that $92 \%$ of respondents strongly agreed 
or agreed with the statement: 'I have skills and experience in running a tourism business'. The results indicate that the majority of managers and owners of tourism businesses have skills and experience to run a tourism business. Nsengimana et al. (2017) argue that business experience influences the chances of business operational success. Notably, respondents in this study agreed more to the statement referring to developing and supporting their subordinates. About $74 \%$ of respondents agreed or strongly agreed with the statement: 'I give my employees the opportunity to come up with ideas or decisions in running the business' and $72 \%$ of respondents agreed or strongly agreed with the statement: 'I arrange workshops for the staff members to receive training'. Kimbu et al. (2019) in this regard, emphasise that skills development is a crucial factor that increase destination competitiveness in the tourism industry. In line with Kim and Brymer (2011), results in this study show that most of the owners and managers possess transformational leadership qualities. Chirwa (2008) argues that compared to men, women lack business training skills and have less business experience to manage their businesses. Respondents in this study however contradict this finding, as about $69 \%$ of respondents strongly disagreed or disagreed with the statement: 'male business managers are more capable than female business managers' and only $14 \%$ respondents strongly agreed or agreed with this statement.

The results in this study show that respondents mostly agreed to a set of variables used in measuring 'marketing capabilities'. About $72 \%$ of respondents strongly agreed or agreed with the statement: 'I use Internet to market my business'; and $74 \%$ strongly agreed or agreed with the statement: 'I rely on different sources of media to get my business known'. Majority of respondents in this study showed that they endeavour to keep up with the market trends, as 78\% of the respondents strongly agreed or agreed with the statement: 'I do research to find out the new market trends'. The statements concerning the marketing-mix strategy (of product and promotion) also receive high levels of agreement. 88\% of respondents strongly agreed or agreed with the statement: 'I know very well how to offer my products and deliver services to meet customer need (Product)'. Also, $80 \%$ of the respondents strongly agreed or agreed with the statement: 'I use different promotion techniques to sell my products and services (Promotion)'. Welsh et al. (2017) maintain that marketing capabilities equip entrepreneurs in growing their businesses and remaining competitive in the market. Results Table 2 also show that respondents mostly perceive themselves to have strong entrepreneurial qualities (see responses regarding 'general entrepreneurial statements'). These are some of the entrepreneurial attributes that strengthen the business operations (Ezeuduji and Ntshangase, 2017a, b).

\section{Perception of entrepreneurial success level versus business operation statements}

Spearman's Rank Correlation test was used to test for relationships between respondents' responses to 'perception of entrepreneurial success level' and 'business operation statements'. Based on the results in Table 3, it is evident that there is no reported correlation between gender nuanced business operation variables and perceived business success level.

Table 3. Correlating perception of entrepreneurial success level versus business operation statements

\begin{tabular}{|l|c|}
\hline \multicolumn{1}{|c|}{ Statements $^{\mathbf{a}}$} & $\begin{array}{c}\text { Correlated with perception of } \\
\text { entrepreneurial success level }^{\mathbf{b}}\end{array}$ \\
\hline 3.1 Managerial and Operational Capabilities & N.S \\
\hline I have skills and experience in running a tourism business & N.S \\
\hline I give my employees the opportunity to come up with ideas or decisions in running the business & N.S \\
\hline Male business managers are more capable than female business managers & $* *$ \\
\hline Male business managers are better managers than female business managers & $* *$ \\
\hline I send/arrange workshops for the staff members to receive training. & $* *$ \\
\hline 3.2 Marketing Capability & $* *$ \\
\hline I use Internet to market my business & $*$ \\
\hline I rely on different sources of media to get my business known. & $* *$ \\
\hline I do research to find out the new market trends & N.S \\
\hline I know very well how to offer my products and deliver services to meet customer need (Product) & N.S \\
\hline I use different promotion techniques to sell my products and services (Promotion) & N.S \\
\hline 3.3 General Entrepreneurial Statements & N.S \\
\hline I always bring new ideas in the business & $* *$ \\
\hline I am ambitious to bring change in my society & N.S \\
\hline I have been a powerful force for helpful change & $*$ \\
\hline I enjoy facing and overcoming obstacles to my ideas & \\
\hline I do not give up easily & \\
\hline I am great at turning problems into opportunities & \\
\hline I can spot a good opportunity easily & \\
\hline
\end{tabular}

${ }^{\mathrm{a} Q u e s t i o n n a i r e ~ w e r e ~ i t e m i s e d ~ a l o n g ~ a ~ 5-p o i n t ~ L i k e r t-t y p e ~ s c a l e ~(b u s i n e s s ~ o p e r a t i o n ~ s t a t e m e n t s): ~ 1, ~ S t r o n g l y ~ a g r e e ; ~ 2, ~ A g r e e ; ~}$ 3, Neutral; 4, Disagree; 5, Strongly disagree. Questionnaire were itemised along a 5-point Likert-type scale (perceptions of entrepreneurial success level): 1, Very successful; 2, Successful; 3, Surviving; 4, Struggling; 5, Unsuccessful

${ }^{\mathrm{b}}$ Spearman's Rank correlation (two-tailed) test significance: **, ${ }_{\mathrm{P}}<0.01$; N.S., no significant results

The variables identified to have positive correlations with perceived business success are mostly found within the dimension of 'marketing capability'. This shows that marketing capability is pivotal to business success, as all the variables within this dimension have mostly very strong positive correlation with business success. Results in this study support the findings of other authors (such as Kimosop et al., 2016; Welsh et al., 2017) who report that there is a positive relationship between marketing capabilities and business performance. According to Welsh et al. (2017), marketing capabilities prepare entrepreneurs to spot and take available opportunities to grow the business and remain competitive in the market. This is in line 
with the other findings of this study. In Table 3, the other variables that show positive influence on entrepreneurial success are those that have to do with 'training of staff members', 'not giving up easily' and 'ability to spot good opportunities easily'. Supportive and transformational leadership, persistence, and identifying opportunities are therefore drivers of business success.

4. Comparing demographic variables with business start-up motivation and perceptions of entrepreneurial success level

We further compared demographic variables of respondents with business start-up motivation and perceptions of entrepreneurial success level (using Pearson's Chi-Square and Mann-Whitney U tests, respectively). As shown in Table 4, results show that there is no significant relationship between 'gender', 'age group', and 'number of years in business' with 'business start-up motivation'. Focussing on the purpose of this study, gender did not explain any choice between being 'opportunity' or 'survival' entrepreneur. However, nationality and educational level were identified as the socio-demographic characteristics that have significant influence on the type of motivation to start a tourism business.

Table 4. Comparing demographic variables with business start-up motivation and perceptions of entrepreneurial success

\begin{tabular}{|c|c|c|c|}
\hline \multicolumn{2}{|c|}{ Statements } & Evidence from analysis & $\begin{array}{l}\text { Compared with respondents' } \\
\text { demographic variables }\end{array}$ \\
\hline \multicolumn{4}{|c|}{ 4.1 Motivation to start tourism business ${ }^{\text {a, } c}$} \\
\hline & & Cross-tabulation results & \\
\hline \multirow{2}{*}{ Nationality } & South Africans & $\begin{array}{l}\text { Expected count for opportunity } \\
\text { entrepreneurs }=71.8 ; \text { Actual count }=79\end{array}$ & \multirow{2}{*}{$\begin{array}{l}\text { ** South Africans are more 'opportunity } \\
\text { entrepreneurs', while Non South Africans are } \\
\text { more 'survival' entrepreneurs }\end{array}$} \\
\hline & Non South Africans & $\begin{array}{l}\text { Expected count for survival } \\
\text { entrepreneurs }=7.6 ; \text { Actual count }=15\end{array}$ & \\
\hline \multirow{2}{*}{ Gender } & Male & & \multirow{2}{*}{ N.S. } \\
\hline & Female & & \\
\hline \multirow{2}{*}{ Age group } & Less than 40 years & & \multirow{2}{*}{ N.S } \\
\hline & 40 years and above & & \\
\hline \multirow[t]{2}{*}{ Level of Education } & Up to Secondary School & $\begin{array}{l}\text { Expected count for opportunity } \\
\text { entrepreneurs }=45.1 ; \text { Actual count }=52\end{array}$ & \multirow{2}{*}{$\begin{array}{l}\text { * Respondents with tertiary education are more } \\
\text { 'opportunity entrepreneurs' while respondents } \\
\text { without tertiary education are more 'survival' } \\
\text { entrepreneurs }\end{array}$} \\
\hline & Tertiary education & $\begin{array}{l}\text { Expected count for survival } \\
\text { entrepreneurs }=29.7 ; \text { Actual count }=37\end{array}$ & \\
\hline \multirow[t]{2}{*}{ No. of years in business } & Up to 6 years & & \multirow{2}{*}{$T_{1}$} \\
\hline & 7years and above & & \\
\hline \multicolumn{4}{|c|}{ 4.2 Perceptions of entrepreneurial success level ${ }^{b, d}$} \\
\hline & & Mean scores & \\
\hline \multirow{2}{*}{ Nationality } & South Africans & 2.42 & \multirow{2}{*}{ N.S. } \\
\hline & Non South Africans & 2.41 & \\
\hline \multirow{2}{*}{ Gender } & Male & 2.49 & \multirow{2}{*}{ N.S. } \\
\hline & Female & 2.35 & \\
\hline \multirow{2}{*}{ Age group } & Less than 40 years & 2.34 & \multirow{2}{*}{ N.S. } \\
\hline & 40 years and above & 2.53 & \\
\hline \multirow{2}{*}{ Level of Education } & Up to Secondary School & 2.79 & \multirow{2}{*}{$\begin{array}{l}\text { ** Respondents with tertiary education agree } \\
\text { to being more successful }\end{array}$} \\
\hline & Tertiary education & 2.12 & \\
\hline \multirow{2}{*}{ No. of years in business } & Up to 6 years & 2.39 & \multirow{2}{*}{ N.S. } \\
\hline & 7 years and above & 2.46 & \\
\hline
\end{tabular}

${ }^{a}$ Questionnaire was itemised categorically: 1, Took opportunity; 2, Means of survival

${ }^{\mathrm{b}}$ Questionnaire were itemised along a 5-point Likert-type scale (perceptions of entrepreneurial success level): 1, Very successful; 2, Successful; 3, Surviving; 4, Struggling; 5, Unsuccessful 'Pearson's Chi-Square test significance: *, ${ }_{\mathbf{P}}<0.05$; ${ }^{*}$, $\mathbf{p}<0.01$; N.S., no significant results ${ }^{\mathrm{d}}$ Mann-Whitney U test significance: ${ }^{*}, \mathbf{P}<0.05 ;{ }^{* *}, \mathbf{P}<0.01 ;$ N.S., no significant results

Results show that respondents who have tertiary education are more 'opportunity' driven entrepreneurs while respondents who do not have tertiary education are more 'survival' driven entrepreneurs. South African respondents are more 'opportunity' entrepreneurs whereas non-South Africans are more 'survival' entrepreneurs. Non-South African entrepreneurs may struggle to find long-term resident permit in South Africa, and may be discriminated against in the labour market. They may therefore decide to start businesses to survive in South Africa. Securing a decent job opportunity in South Africa may also prove difficult for those without tertiary education, hence they may end up becoming 'survival' entrepreneurs. These results support Mersha and Sriram's (2019) argument that socio-economic challenges may lead individuals to start a business (as means of survival).

Also, based on the results in Table 4, the only socio-demographic characteristic that has a significant influence on 'entrepreneurial success level' is the 'level of formal education'. Respondents with tertiary education perceived themselves more successful than those without tertiary education. According to Nxopo and Iwu (2016), and Rao (2018), formal education equips entrepreneurs with skills (such as financial management, use of technology, sourcing of information) to effectively manage business operations. Formal education serves as basis for accessing and utilising information to run a business successfully (Iwu and Nxopo, 2015). Also relating to this study's finding, lack of formal education has been labelled a major challenge towards business operations' success (Chinomona and Maziriri, 2015; Daniyan-Bagudu et al., 2016; Nsengimana et al., 2017). Entrepreneurs with higher level of education are better prepared to handle entrepreneurial challenges that may arise in the business (Meunier et al., 2017), and be able to operate the business successfully. 


\section{Comparing gender identity with business operation statements}

The respondents were asked to indicate their level of agreement or disagreement with business operations' variables; their responses were then compared with respondents' gender. This study employed Mann-Whitney U test to check if there are significant relationships between gender identity and the business operations variables. Results in Table 5 show that male entrepreneurs showed stronger managerial capabilities than female entrepreneurs, regarding the statements: 'I give my employees the opportunity to come up with ideas or decisions in running the business', and 'I send/arrange workshops for the staff members to receive training'. These results contradict some of the previous findings (Guillet et al., 2019a; Schaap et al., 2008) that women are more transformational business leaders than men. Therefore, from the findings of this study, compared to previous findings, transformational leadership can be argued not to be gender specific.

The results in Table 5 indicate that there is no significant difference between male and female mean scores regarding their responses to the variables within the 'marketing capability' dimension. These results suggest that both male and female entrepreneurs have similar levels of marketing capabilities. This study did not identify significant differences between male and female respondents when gender identity was compared with the responses on 'general entrepreneurial statements'. Hence, neither gender can claim to be more entrepreneurial.

Table 5. Comparing gender identity with business operation statements

\begin{tabular}{|c|c|c|c|}
\hline Statements ${ }^{\mathbf{a}}$ & $\begin{array}{c}\text { Mean score } \\
\text { (Males) }\end{array}$ & $\begin{array}{c}\text { Mean score } \\
\text { (Females) }\end{array}$ & $\begin{array}{c}\text { Compared } \\
\text { with gender }^{b}\end{array}$ \\
\hline \multicolumn{4}{|l|}{ 5.1 Managerial and Operational Capabilities } \\
\hline I have skills and experience in running a tourism business & 1.77 & 1.75 & N.S. \\
\hline I give my employees the opportunity to come up with ideas or decisions in running the business & 1.91 & 2.27 & ** Males agree more \\
\hline Male business managers are more capable than female business managers & 3.45 & 3.72 & N.S. \\
\hline Male business managers are better managers than female business managers & 3.47 & 3.75 & N.S. \\
\hline I send/arrange workshops for the staff members to receive training. & 1.91 & 2.36 & * Males agree more \\
\hline \multicolumn{4}{|l|}{ 5.2 Marketing Capability } \\
\hline I use Internet to market my business & 1.93 & 2.15 & N.S. \\
\hline I rely on different sources of media to get my business known. & 2.12 & 2.21 & N.S. \\
\hline I do research to find out the new market trends & 1.83 & 2.20 & N.S. \\
\hline I know very well how to offer my products and deliver services to meet customer need (Product) & 1.89 & 1.69 & N.S. \\
\hline I use different promotion techniques to sell my products and services (Promotion) & 1.85 & 2.07 & N.S. \\
\hline \multicolumn{4}{|l|}{5.3 General Entrepreneurial Statements } \\
\hline I always bring new ideas in the business & 1.60 & 1.76 & N.S. \\
\hline I am ambitious to bring change in my society & 1.80 & 1.93 & N.S. \\
\hline I have been a powerful force for helpful change & 1.88 & 2.17 & N.S. \\
\hline I enjoy facing and overcoming obstacles to my ideas & 1.72 & 1.86 & N.S. \\
\hline I do not give up easily & 1.44 & 1.44 & N.S. \\
\hline I am great at turning problems into opportunities & 1.76 & 1.75 & N.S. \\
\hline I can spot a good opportunity easily & 1.75 & 1.71 & N.S. \\
\hline
\end{tabular}

${ }^{\mathrm{a}}$ Questionnaire were itemised along a 5-point Likert-type scale (business operation statements): 1, Strongly agree; 2, Agree; 3, Neutral; 4, Disagree; 5, Strongly disagree; ${ }^{b}$ Mann-Whitney U test significance: ${ }^{*},{ }_{\mathrm{P}}<0.05$; $^{*},{ }_{\mathrm{P}}<0.01$; N.S., no significant results

\section{CONCLUSIONS AND RECOMMENDATION}

We explored nuanced gender perceptions regarding the influences that business capabilities may have on tourism-related business operations; and also sought if gender identity drives business performance, using the case of Durban Central Business District, in KwaZulu-Natal, South Africa. Our results reveal no correlation between gender nuanced business operation variables and perceived business success level. The variables identified to have positive correlations with perceived business success are mostly found within the dimension of 'marketing capability'. This shows that marketing capability is pivotal to business success, as all variables within this dimension have mostly very strong positive correlation with business success. Also this study found that the entrepreneur's supportive and transformational leadership, persistence, and ability to identify opportunities are other drivers of business success. Gender did not explain any choice between being 'opportunity' or 'survival' entrepreneur. The only socio-demographic characteristic that has a significant influence on 'entrepreneurial success level' is the 'level of formal education'. Respondents with tertiary education perceived themselves more successful than those without tertiary education. This study reveals no convincing differences between male and female respondents regarding their responses on 'managerial and operational capabilities', 'marketing capability' and 'general entrepreneurial statements'. Therefore, being male or female does not make an entrepreneur a better business manager. This study therefore recommends business mentorship programmes and more entrepreneurship trainings in KwaZulu-Natal, South Africa; and these should emphasise that formal education, marketing capability and other factors (but not gender) support business success. Hence training and mentorship should focus on building marketing capability, among others.

\section{REFERENCES}

Biernacka, A., Abu-Rabia-Queder, S., \& Kressel, G.M. (2018). The Connective Strategies of Bedouin Women Entrepreneurs in the Negev. Journal of Arid Environments, 149, 62-72. https://doi.org/10.1016/j.jaridenv.2017.10.004

Ceptureanu, S.I., \& Ceptureanu, E.G. (2016). Women Entrepreneurship in Romania: The Case of North East Development Region. Management and Economics Review, 1(1), 20-32. http://mer.ase.ro/files/2016-1/2.pdf 
Chawla, D., \& Sondhi, N. (2011). Research Methodology: Concepts and Cases. London: New Delhi. Vikas Publishing.

Chetty, M. (2015). How Women Entrepreneurs Can Use Digital Marketing to Their Advantage. [Accessed 2019, August 12]. https:// yourstory.com/2015/08/women-entrepreneurs-use-digital-marketing-to-advantage

Chinomona, E., \& Maziriri, E.T. (2015). Women in Action: Challenges Facing Women Entrepreneurs in the Gauteng Province of South Africa. International Business \& Economics Research Journal, 14(6), 835-850. https://doi.org/10.19030/iber.v14i6.9487

Chirwa, E.W. (2008). Effects of Gender on the Performance of Micro and Small Enterprises in Malawi. Development Southern Africa, 25(3), 347-362. https://doi.org/10.1080/03768350802212139

Daniyan-Bagudu, H., Khan, S.J.M., \& Roslan, A.H. (2016). The Issues and Challenges Facing the Female Entrepreneurs in Lagos State, Nigeria. 3rd Kanita Postgraduate International Conference on Gender Studies, Universiti Sains Malaysia, Penang, 149-155.

Etikan, I., Musa, S.A., \& Alkassim, R.S. (2016). Comparison of Convenience Sampling and Purposive Sampling. American Journal of Theoretical and Applied Statistics, 5(1), 1-4. https://doi.org/10.11648/j.ajtas.20160501.11

Ezeuduji, I.O., \& Nkosi, S. (2017). Tourism Destination Competitiveness using Brand Essence: Incorporating the 'Zuluness' of the Zulu Kingdom. African Journal of Hospitality, Tourism and Leisure, 6(1), 1-10. http://www.ajhtl.com/uploads/7/1/6/3/7163688/article_7_vol_6_1_2017.pdf

Ezeuduji, I.O., \& Ntshangase, S.D. (2017a). Entrepreneurial Intention: South African Youth's willingness to start Tourism Businesses. Acta Universitatis Danubius Economica, 13(5), 48-58. http://journals.univ-danubius.ro/index.php/oeconomica/article/view/4165/4414

Ezeuduji, I.O., \& Ntshangase, S.D. (2017b). Entrepreneurial Inclination: South African Youth's Mental Attitude towards starting Tourism Business. Journal of Economics and Behavioural Studies, 9(4), 144-152. https://doi.org/10.22610/jebs.v9i4(J).1829

Fairlie, R.W., \& Robb, A.M. (2009). Gender Differences in Business Performance: Evidence from the Characteristics of Business Owners survey. Small Business Economics, 33(4), 375-395. https://doi.org/10.1007/s11187-009-9207-5

Ferguson, L. (2011). Promoting gender equality and empowering women? Tourism and the third millennium development goal. Current Issues in Tourism, 14(3), 235-249. https://doi.org/10.1080/13683500.2011.555522

Finn, M., Elliot-White, M., \& Walton, M. (2000). Tourism and Leisure Research Methods. Harlow: Pearson Education Limited.

George, D., \& Mallery, P. (2003). SPSS for Windows step by step: A simple guide and reference. 11.0 update. Boston, Allyn \& Bacon.

Gidarakou, I. (2015). Women's Entrepreneurship in Rural Greece. International Journal of Business and Management, 10(10), 129-142. http://dx.doi.org/10.5539/ijbm.v10n10p129

González-Sánchez, V.M. (2015). Factors Promoting Entrepreneurship in European Countries: Unemployment, Taxes, and Education. Journal of Promotion Management, 21(4), 492-503. https://doi.org/10.1080/10496491.2015.1051405

Guillet, B.D., Pavesi, A., Hsu, C.H.C., \& Weber, K. (2019a). Is There Such Thing as Feminine Leadership? Being a Leader and Not a Man in the Hospitality Industry. International Journal of Contemporary Hospitality Management, 31(7), 2970-2993. https://doi.org/10.1108/IJCHM-06-2018-0486

Guillet, B.D., Pavesi, A., Hsu, C.H.C., \& Weber, K. (2019b). What Can Educators Do to Better Prepare Women for Leadership Positions in the Hospitality Industry? The Perspectives of Women Executives in Hong Kong. Journal of Hospitality \& Tourism Education, 31(4), 197-209. https://doi.org/10.1080/10963758.2019.1575751

Hassan, F., Ramli, A., \& Desa, N.M. (2014). Rural Women Entrepreneur in Malaysia: What Drives Their Success? International Journal of Business and Management, 9(4), 10-21. https://doi.org/10.5539/ijbm.v9n4p10

Iwu, C.G., Ezeuduji, I.O., Eresia-Eke, C., \& Tengeh, R. (2016). The Entrepreneurial Intention of University Students: The Case of a University of Technology in South Africa. Acta Universitatis Danubius Economica, 12(1), 164-181. http://journals.univdanubius.ro/index.php/oeconomica/article/view/3129/3216

Iwu, C.G., \& Nxopo, Z. (2015). Determining the specific support services required by female entrepreneurs in the South African tourism industry. African Journal of Hospitality, Tourism and Leisure, 4(2), 1-13. http://www.ajhtl.com/uploads/7/1/6/3/7163688/article22vol4(2)july-nov2015.pdf

Jiyane, V. (2014). Challenges of e-society for Informal Sector Women Entrepreneurs of Hlabisa Local Municipality in KwaZulu-Natal, South Africa. Innovation: Journal of Appropriate Librarianship and Information Work in Southern Africa, 48, 87-112. https://hdl.handle.net/10520/EJC164637

Jovicic, D.Z. (2019). From The Traditional Understanding of Tourism Destination to the Smart Tourism Destination. Current Issues in Tourism. 22(3), 276-282. https://doi.org/10.1080/13683500.2017.1313203

Kim, W.G., \& Brymer, R.A. (2011). The Effects of Ethical Leadership on Manager Job Satisfaction, Commitment, Behavioural Outcomes, and Firm Performance. International Journal of Hospitality Management, 30(4), 1020-1026. https://doi.org/10. 1016/j.ijhm.2011.03.008

Kimbu, A.N., Ngoasong, M.Z., Adeola, O., \& Afenyo-Agbe, E. (2019). Collaborative Networks for Sustainable Human Capital Management in Women's Tourism Entrepreneurship: The Role of Tourism Policy. Tourism Planning \& Development, 16(2), 161-178. https://doi.org/10.1080/21568316.2018.1556329

Kimosop, J., Korir, M., \& White, M. (2016). The Moderating Effect of Demographic Characteristics on the Relationship between Strategic Capabilities and Firm Performance in Women-Owned Entrepreneurial Ventures in Nairobi, Kenya. Canadian Journal of Administrative Sciences, 33(3), 242-256. https://doi.org/10.1002/cjas.1399

Kokotović, D., Rakić, B., \& Kokotović, T. (2016). Female Entrepreneurship: Main Challenges and the Impact of Gender Gap. Proceedings of the XV International Symposium of Organisational Sciences: Reshaping the Future through Sustainable Business Development and Entrepreneurship. Belgrade, Serbia, 504-512.

Manzanera-Román, S., \& Brändle, G. (2016). Abilities and Skills as Factors Explaining the Differences in Women Entrepreneurship. Suma De Negocios, 7(15), 38-46. https://doi.org/10.1016/j.sumneg.2016.02.001

Maurya, C.D., \& Sharma, A.K. (2017). The Role of Managerial Skills in Success of an Organization. International Journal of Research in Commerce and Management, 8(6), 12-14.

Marlow, S., \& McAdam, M. (2013). Gender and entrepreneurship: Advancing debate and challenging myths; exploring the mystery of the under-performing female entrepreneur. International Journal of Entrepreneurial Behaviour \& Research, 19(1), 114-124. https://doi.org/10.1108/13552551311299288

Mersha, T., \& Sriram, V. (2019). Gender, Entrepreneurial Characteristics, and Success: Evidence from Ethiopia. Thunderbird International Business Review, 61(2), 157-167. https://doi.org/10.1002/tie.21984

Meunier, F., Krylova, Y., \& Ramalho, R. (2017). Women's Entrepreneurship: How to Measure the Gap Between New Female and Male Entrepreneurs? Policy Research Working Paper, 8242, 1-28. World Bank Group. [Accessed 2020, April 2]. https://elibrary.worldbank. org/doi/pdf/10.1596/1813-9450-8242 
Mkhize, G., \& Cele, N. (2017). The role of women in tourism in KwaZulu-Natal. Agenda, 31 (1), 128-139. https://doi.org/10. 1080/10130950.2017.1371527

Moses, C.L., Olokundun, M., Falola, H., Ibidunni, S., Amaihian, A., \& Inelo, F. (2016). A Review of the Challenges Militating Against Women Entrepreneurship in Developing Nations. Mediterranean Journal of Social Sciences, 7(1), 64-69. https://doi.org/10.5901/mjss.2016.v7n1p64

Nardi, P.M. (2018). Doing Survey Research: A Guide to Quantitative Methods. New York, Routledge Publications.

Nsengimana, S., Iwu, C.G., \& Tengeh, R.K. (2017). The Downside of Being a Female Entrepreneur in Kigali, Rwanda. The Scientific Journal for Theory and Practice of Socio-economic Development, 6(12), 151 - 164. http://dx.doi.org/10.12803/SJSECO.61203

Nxopo, Z., \& Iwu, C.G. (2016). The Unique Obstacles of Female Entrepreneurship in the Tourism Industry in Western Cape, South Africa. Commonwealth Youth and Development, 13(2), 55-71. https://doi.org/10.25159/1727-7140/1146

Nyaruwata, S., \& Nyaruwata, L.T. (2013). Gender Equity and Executive Management in Tourism: Challenges in the Southern African Development Community (SADC) Region. African Journal of Business Management, 7(21), 2059-2070. https://doi.org/10.5897/AJBM2013.1592

Nzama, N., \& Ezeuduji, I.O. (2020a). Gender Nuances in Tourism-Related Entrepreneurship in Kwazulu-Natal, South Africa. African Journal of Gender, Society and Development (AJGSD), 9(4), 109-137. https://doi.org/10.31920/2634-3622/2020/v9n4a5

Nzama, N., \& Ezeuduji, I.O. (2020b). Nuanced Gender Perceptions on the Influences of Formal Education and Business Networks on Tourism-Related Business Operations: Kwazulu-Natal, South Africa. EuroEconomica, 39(2) (Special Issue), 70-84. http://dj.univdanubius.ro/index.php/EE/article/view/292/477

Okeke-Uzodike, O.E., Okeke-Uzodike, U., \& Ndinda, C. (2018). Women entrepreneurship in Kwazulu-Natal: A critical review of government intervention politics and programs. Journal of International Women's Studies, 19(5), 147-164. http://hdl.handle.net/20.500.11910/12319

Orser, B.J., \& Riding, A. (2018). The Influence of Gender on the Adoption of Technology among SMEs. International Journal of Entrepreneurship and Small Business, 33(4), 514-531. https://doi.org/10.1504/IJESB.2018.090341

Ramadani, V. (2015). The Woman Entrepreneur in Albania: An Exploratory Study on Motivation, Problems and Success Factors. Journal of Balkan and Near Eastern Studies, 17(2), 204-221. https://doi.org/10.1080/19448953.2014.997488

Rao, D.K. (2018). Growth and Development of Women Entrepreneurs in India Challenges and Empowerment. International Journal of Advanced Research and Development, 3(1), 235-242. http://www.advancedjournal.com/archives/2018/vol3/issue1/3-1-90

Sarfaraz, L., Faghih, N., \& Majd, A.A. (2014). The relationship between women entrepreneurship and gender equality. Journal of Global Entrepreneurship Research, 2(6), 1-11. https://journal-jger.springeropen.com/articles/10.1186/2251-7316-2-6

Schaap, J.I., Stedham, Y., \& Yamamura, J.H. (2008). Casino Management: Exploring Gender-based Differences in Perceptions of Managerial Work. International Journal of Hospitality Management, 27(1), 87-97. https://doi.org/10.1016/j.ijhm.2007.07.004

Seyedinejat, S.S., Razaghi, M.E., \& Dousti, M. (2014). Prioritizing Managerial Skills Based on Katz's Theory Cast Study: The Managers of Sports and Youth in Mazandaran Province. Pamukkale Journal of Sport Sciences, 5(1), 33-47. http://psbd.pau.edu.tr/index. php/pjss/article/view/179/119

Shepard, L.J. (2015). Gender Matters in Global Politics: A Feminist Introduction to International Relations. New York: Routledge.

Sudarmanti, R., Van Bauwel, S., \& Longman, C. (2013). The Importance of Fieldwork Research to Reveal Women Entrepreneurs Competence in Communication. Journal of Women's Entrepreneurship and Education, 3(4), 74-87. https://econpapers.repec.org/ RePEc:ibg:jwejou:y:2013:i:3-4:p:74-87

Tajeddini, K., Ratten, V., \& Denisa, M. (2017). Female Tourism Entrepreneurs in Bali, Indonesia. Journal of Hospitality and Tourism Management, 31, 52-58. https://doi.org/10.1016/j.jhtm.2016.10.004

Tavakol, M., \& Dennick, R. (2011). Making Sense of Cronbach's alpha. International Journal of Medical Education, 2(1), 53-55. https://doi.org/10.5116/ijme.4dfb.8dfd

Todorović, I., Komazec, S., Miloš, J., Obradović, V., \& Marič, M. (2016). Strategic Management in Development of Youth and Women Entrepreneurship - Case of Serbia. Organizacija, 49(4), 197-207. https://doi.org/10.1515/orga-2016-0018

Tshabalala, S.P., \& Ezeuduji, I.O. (2016). Women Tourism Entrepreneurs in KwaZulu-Natal, South Africa: Any Way Forward? Acta Universitatis Danubius Economica, 12(5), 19-32. http://journals.univ-danubius.ro/index.php/oeconomica/article/view/3336/3666

Vázquez-Carrasco, R., López-Pérez, M.E., \& Centeno, E. (2012). A Qualitative Approach to the Challenges for Women in Management: Are They Really Starting in the 21st Century? Quality \& Quantity, 46, 1337-1357. https://doi.org/10.1007/s11135-011-9449-6

Veal, A.J. (2011). Research Methods for Leisure and Tourism: A Practical Guide. Harlow, Financial Times Prentice Hall.

Vossenberg, S. (2013). Women Entrepreneurship Promotion in Developing Countries: What Explains the Gender Gap in Entrepreneurship and How to Close it? Working Papers from Maastricht School of Management, [Accessed 2020, February 2]. https://econpapers. repec.org/paper/msmwpaper/2013_2f08.htm

Welsh, D.H.B., Kaciak, E., Memili, E., \& Zhou, Q. (2017). Work-Family Balance and Marketing Capabilities as Determinants of Chinese Women Entrepreneurs' Firm Performance. Journal of Global Marketing, 30(3), 174-191. https://doi.org/10.1080/08911762.2017.1317894

Wessels, W., Du Plessis, E., \& Slabbert, E. (2017). Key Competencies and Characteristics of Accommodation Managers. SA Journal of Human Resource Management, 15, 1-11. https://doi.org/10.4102/sajhrm.v15i0.887

Witbooi, M., \& Ukpere, W. (2011). Indigenous Female Entrepreneurship: Analytical Study on Access to Finance for Women Entrepreneurs in South Africa. African Journal of Business Management, 5(14), 5646-5657. https://doi.org/10.5897/AJBM10.1161

Yadav, O.P. (2018). Study on Internet Marketing Practices of Tourism Industry by Travel Agency of Nepal. Pravaha Journal, 24(1), 137146. https://doi.org/10.3126/pravaha.v24i1.20233

Zeng, B., \& Gerritsen, R. (2014). What Do We Know About Social Media in Tourism? A Review. Tourism Management Perspectives, 10, 27-36. http://dx.doi.org/10.1016/j.tmp.2014.01.001

*** Business Environment Specialist (2013). Understanding Women Entrepreneurs in South Africa. [Accessed 2018, May 11]. http://www.sbp.org.za/uploads/media/SBP_Alert_Understanding_Women_Entrepreneurs_in_SA.pdf.

*** GEM (2012). Global Entrepreneurship Monitor 2012 Women's Report. [Accessed 2019, July 22]. https://www.gemconsortium. org/report/gem-2012-womens-report

*** Tourism KwaZulu-Natal (2019). Tourism boom. [Accessed 2019, February 28]. https://www.zulu.org.za/

Article history: Received: 03.11.2020 Revised: 12.03.2021 Accepted: 20.04.2021 Available online: 12.05 .2021

